University of Nebraska - Lincoln

DigitalCommons@University of Nebraska - Lincoln

\title{
Characteristics of white-tailed deer visits to cattle farms: Implications for disease transmission at the wildlife-livestock interface
}

\author{
Are R. Berentsen \\ USDA National Wildlife Research Center, Are.R.Berentsen@aphis.usda.gov \\ Ryan S. Miller \\ USDA APHIS, Ryan.S.Miller@aphis.usda.gov \\ Regina Misiewicz \\ USDA APHIS
}

Jennifer L. Malmberg

USDA APHIS

Mike R. Dunbar

USDA-APHIS, NWRC, Fort Collins, CO., mike.r.dunbar@aphis.usda.gov

Follow this and additional works at: https://digitalcommons.unl.edu/zoonoticspub

Part of the Agriculture Commons, and the Biology Commons

Berentsen, Are R.; Miller, Ryan S.; Misiewicz, Regina; Malmberg, Jennifer L.; and Dunbar, Mike R., "Characteristics of white-tailed deer visits to cattle farms: Implications for disease transmission at the wildlife-livestock interface" (2013). Other Publications in Zoonotics and Wildlife Disease. 170.

https://digitalcommons.unl.edu/zoonoticspub/170

This Article is brought to you for free and open access by the Wildlife Disease and Zoonotics at DigitalCommons@University of Nebraska - Lincoln. It has been accepted for inclusion in Other Publications in Zoonotics and Wildlife Disease by an authorized administrator of DigitalCommons@University of Nebraska Lincoln. 


\title{
Characteristics of white-tailed deer visits to cattle farms: implications for disease transmission at the wildlife-livestock interface
}

\author{
Are R. Berentsen • Ryan S. Miller • Regina Misiewicz • \\ Jennifer L. Malmberg • Mike R. Dunbar
}

Received: 26 February 2013 /Revised: 19 July 2013 / Accepted: 23 July 2013

(C) Springer-Verlag Berlin Heidelberg (outside the USA) 2013

\begin{abstract}
Bovine tuberculosis (bTB) is endemic in freeranging white-tailed deer (Odocoileus virginianus) in MI, USA. Currently, the rates of farm visitation by deer and couse of forage resources by cattle and deer are poorly understood. To evaluate the extent deer and livestock may share forage resources, we investigated farm, yard, and cattle-use area visitation by white-tailed deer and compared visitation with common livestock management practices. We fitted 25 female white-tailed deer near the bTB-infected zone in Michigan's Lower Peninsula with global positioning system collars. Livestock management practices associated with farm visitation included presence of confined feeding pastures, number of cattle water sources, and the number of cattle pastures. Fewer farm visits occurred at night than during the day. A higher proportion of nighttime visits occurred between midnight and sunrise. Visitation to yards and cattle-use areas were similar: a higher proportion of visits occurred at night, and a higher proportion of nighttime visits occurred between midnight and sunrise. Multiple visits during the same day were common. Visitation increased through spring and peaked during the fawning season. Results suggest that mitigation and control efforts to guard against potential transmission of bTB should include the season and time of day during which deer visitation occurs. Furthermore, specific livestock management practices may contribute to farm visitation by deer. Deer visiting multiple farms may contribute to local area spread of bTB.
\end{abstract}

Communicated by C. Gortázar

A. R. Berentsen $(\triangle) \cdot$ R. Misiewicz $\cdot$ M. R. Dunbar

USDA/APHIS/Wildlife Services, National Wildlife Research Center,

4101 LaPorte Avenue, Fort Collins, CO 80521, USA

e-mail: Are.R.Berentsen@aphis.usda.gov

R. S. Miller · J. L. Malmberg

USDA/APHIS/Veterinary Services, Centers for Epidemiology and

Animal Health, 2150B Center Avenue, Fort Collins, CO 80526, USA

R. S. Miller

e-mail: ryan.s.miller@aphis.usda.gov
Focusing risk mitigation efforts on individual deer that are most likely to visit farms may reduce potential bTB transmission.

Keywords Bovine tuberculosis $\cdot$ Cattle $\cdot$ Farm $\cdot$ Interface $\cdot$ Livestock $\cdot$ Michigan $\cdot$ Mycobacterium bovis .

Odocoileus virginianus . White-tailed deer · Wildlife

\section{Introduction}

A thorough understanding of space use by wildlife and domestic livestock is essential when studying shared diseases. Overlapping space use can lead to interspecific interactions resulting in disease spread (Riley et al. 1998). In addition, sharing environmental resources has been identified as a mechanism for disease transmission between wildlife to livestock (Roper et al. 2003; Palmer et al. 2004; Böhm et al. 2009). Thus, to gain insight into the dynamics of disease transmission it is necessary to examine how animals use forage resources and where and when potential interspecific contact may result. Understanding wildlife movements in relation to interactions with domestic livestock, livestock facilities, and shared resources may elucidate potential transmission routes, improving mitigating measures that can prevent disease spread.

Spread of disease from wildlife to livestock has been documented for many species. In North America, it is estimated that at least $79 \%$ of emerging infectious diseases have a wildlife-livestock component (Miller et al. 2012). European starlings (Sturnus vulgaris) may spread salmonella (Salmonella enterica) between cattle feedlots (Linz et al. 2007; Carlson et al. 2011) and dairy cattle diagnosed with paratuberculosis (Mycobacterium avium paratuberculosis) were correlated with red deer (Cervus elaphus) farm use (Fredriksen et al. 2004). European badgers (Meles meles) and brushtail possums (Trichosurus vulpecula) are implicated in bovine tuberculosis (bTB) transmission to cattle in the United Kingdom (UK) (Gallagher and Clifton-Hadley 2000) 
and New Zealand (Coleman 1988; Coleman and Cooke 2001), respectively. Furthermore, deer species have been implicated in the transmission of bTB in the UK (Delahay et al. 2002). However, in the United States of America (USA) questions remain regarding mechanisms of disease transmission between wildlife and cattle, particularly for bTB.

Bovine tuberculosis was common in US domestic cattle throughout the twentieth century. However, test and slaughter programs resulted in eradication from most states by 1992 (Frye 1995). While cases of bTB in North American wildlife have been documented periodically since 1923, they were considered rare (Miller and Sweeney 2013). This changed when bTB was identified in white-tailed deer (Odocoileus virginianus) in a five-county area in Michigan's northeastern Lower Peninsula in 1994 (Schmitt et al. 1997). By 1998, bTB was identified in both cattle and deer (Schmitt et al. 2002). Genetic analysis of $M$. bovis strains suggests interspecific transmission between deer and cattle (Millian-Suazo et al. 2008). A similar situation was documented in Minnesota in 2005 (Portacci et al. 2008). The relative importance of interspecific and intraspecific transmission of M. bovis, once established in a population, is not well understood, although transmission between deer and cattle is considered a risk. Indirect transmission of $M$. bovis between farms via deer is considered a likely route of transmission based on epidemiological investigations of historically infected farms (Portacci et al. 2010).

Bovine tuberculosis infection typically occurs through inhalation of aerosolized bacilli or by direct nose-to-nose contact between animals, but the precise route of bTB transmission between deer and cattle is poorly understood (Cosivi et al. 1998; Kaneene and Pfeiffer 2006). Studies by Palmer et al. (2004), suggest indirect contact resulting from shared feed is a likely mechanism for intraspecific transmission between deer and interspecific transmission between deer and cattle. Epidemiologic investigations of infected white-tailed deer in Michigan found supplemental feeding of deer likely contributes to infection in deer with subsequent spillover to cattle (Miller et al. 2003). Despite reduced population densities and restricted recreational feeding of deer, bTB continues to persist in free-ranging deer populations (O'Brien et al. 2011). Moreover, an average of 4.1 cattle herds are infected in Michigan annually and attributed to contact with bTB-positive deer (Portacci et al. 2008; Portacci et al. 2010). However, the frequency of farm visitation by white-tailed deer, and the risk of disease transmission to livestock via ingestion of bTB contaminated feed, has not been documented.

Here, we use white-tailed deer marked with radio collars equipped with a global positioning system (GPS), along with livestock management practice data to test hypotheses about the influence of farm infrastructure and animal husbandry on the deer visitation of farms. Specifically, this study hypothesized that farm infrastructure related to cattle feeding (e.g., confined feeding and feed storage) was associated with deer visitation of farms. The study also examined the influence of time on visitation of farms, hypothesizing that farm visitation would be greatest in winter when forage resources are limited. Objectives were to identify livestock management practices associated with farm visitation and identify daily and seasonal patterns in deer movements on and near cattle farms. A more thorough understanding of the temporal characteristics and mechanisms driving cattle farm visitation by deer will allow wildlife managers, livestock authorities, and livestock owners to employ better bTB mitigation measures such as targeted vaccination or selective removal.

\section{Materials and methods}

Study site

Our study was conducted in Alcona, Alpena, and Montmorency Counties within the five-county bTB outbreak zone in Michigan's Lower Peninsula (Fig. 1). Regional habitat is dominated by forests of jack pine, white pine, and maple. Agricultural habitat consists of pasture, row crops, and livestock (primarily cattle) farms. Density of cattle farms is low, averaging one farm per $21.5 \mathrm{~km}^{2}$ and $130.0 \mathrm{~km}^{2}$ for beef and

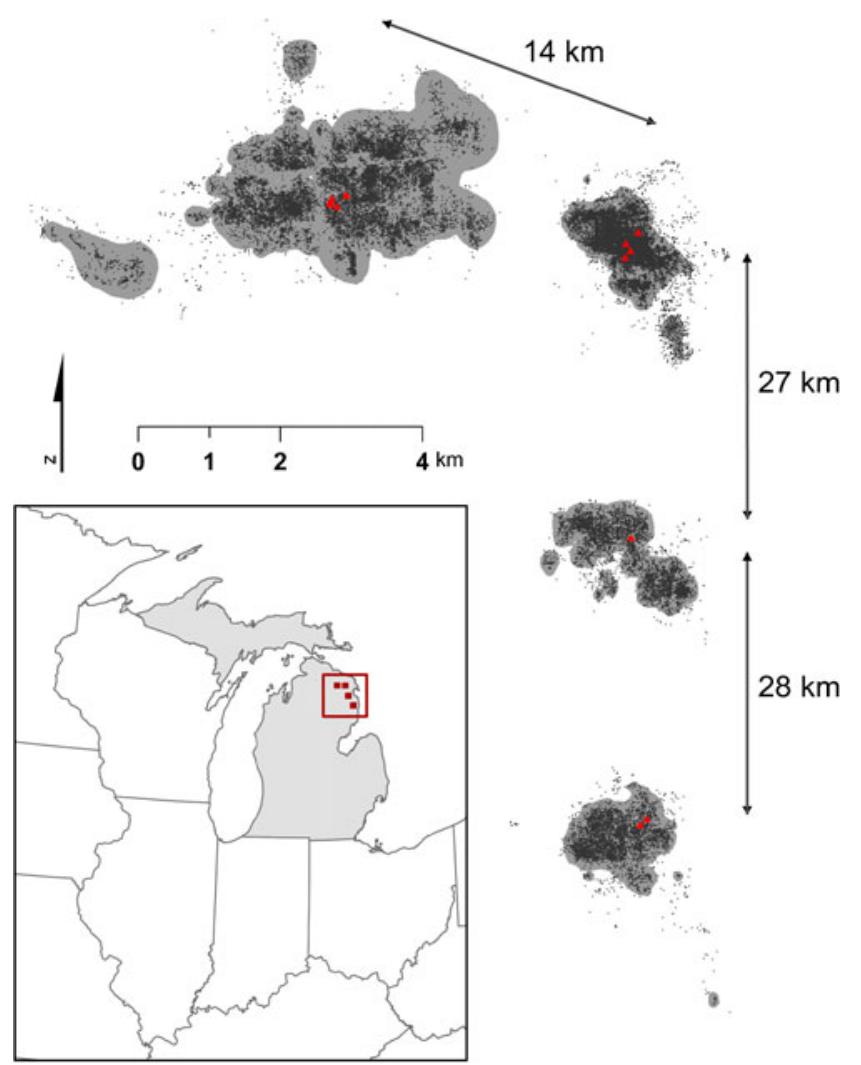

Fig. 1 Location of study sites within the 3-county study area in Michigan's Northeastern Lower Peninsula including deer home ranges (gray), deer locational fixes (black dots), and trap sites (red triangles). Distances between study sites are noted by arrows 
dairy, respectively. Beef farms are small with $93 \%$ of farms having fewer than 50 cattle of all ages. Dairy farms are small by industry standards with $87 \%$ having fewer than 200 cattle of all ages (Anonymous 2007). The white-tailed deer population in the study area is intensively managed to control bTB with current deer densities ranging from 7.9-11.6 deer $/ \mathrm{km}^{2}$ (Frawley and Rudolph 2008; O'Brien et al. 2011).

\section{Capture and handling}

Free-ranging white-tailed deer were captured on four cattle farms during two winters: January through March 2007 and 2008. Capture farms were selected based on the following criteria: landowner interest, a minimum of 20 head of cattle of all ages on the farm year-round, visual evidence of deer (tracks, feces, etc.) on the property, high ( $3 \mathrm{~m})$ fencing surrounding stored feed and suitable deer habitat. Capture farms ranged in size from $30-160$ ha. Netted-cage traps were distributed in lightly forested areas (which provided a measure of thermal cover) across farms and baited with shelled corn, molasses, and apples, or applesauce (VerCauteren et al. 1999). Deer were captured, physically restrained, and blindfolded. Uniquely numbered ear tags and radio collars equipped with a store-on-board GPS (Advanced Telemetry Solutions, Inc., Isanti, Minnesota) were attached. Only adult deer were collared; fawns were released. Collars weighed $\sim 360$ g, roughly $0.7 \%$ of a female deer's body mass, substantially less than the $5-10 \%$ of body mass recommended for maximum collar weight (Gannon and Sikes 2007). Collars were programmed to collect location data at 2-h intervals each day for 1 year except during July and September when data was collected at two-hour intervals every 5 days to conserve battery life.

\section{Data analysis}

Location data were processed using a Geographical Information System (ArcGIS v.9.2, ESRI, Redlands, California). Data were evaluated for accuracy by assessing the positional error of the GPS collar using the dilution of precision (DOP). To avoid errors in classification of farm visits, locations representing low confidence positional measurements $(\mathrm{DOP}>10)$ were excluded from analysis. To limit potential behavior bias resulting from trapping and handling, the first $72 \mathrm{~h}$ of data were excluded from analysis for all deer (White and Garrot 1990; Morellet et al. 2009). Annual home ranges for each deer were generated using a modified least-squares cross validation estimator for $95 \%$ fixed kernel (Silverman 1986).

Landscape features within each deer home range were classified using data from the United States Department of Agriculture, National Cartography and Geospatial Center (USDA 2007). Six categories were used to describe anthropogenic landscape features: (1) cultivated crops, (2) pasture/hay, (3) roads/driveways, (4) buildings, (5) yards, and (6) cattle-use areas. Site visits were conducted to verify the landscape features and informal interviews with landowners were conducted to identify farm boundaries and collect information concerning fifteen variables defining farm infrastructure, cattle feeding practice, and human activity. Specific information collected included: number of cattle of all ages $(\leq 20,>20)$, confined feeding area (fenced paddocks used exclusively for feeding cattle; present, absent), number of pastures $(\leq 2,>2)$, feed storage (present, absent), hay storage (confined/unconfined), grain storage (confined/unconfined), number cattle water sources $(\leq 1,>1)$, cattle feeding time (evening/day), grain feeding (conducted/not conducted), hay feeding (conducted/not conducted), time of hay feeding (winter/summer), type of hay feeding (chip/bales), number of dogs $(\leq 1,>1)$, dog storage (confined/unconfined), deer hunting (conducted/not conducted). In addition the physical location of areas used by cattle, confined feeding areas, calving pastures, stored cattle feed, and cattle water sources (water tubs) were identified and mapped. Farms were defined as all contiguous land holdings, including cattle pastures and building infrastructure, used by a single producer for cattle production. Yards were defined as a contiguous area that included only the farmhouses, barns, outbuildings, cattle feed storage areas, and confined feeding areas. Cattle-use areas constituted pastures occupied at some point during the study by cattle.

To estimate visitation to farms, yards, and cattle-use areas, deer locations were overlaid with farms, yards, and cattle-use areas and then calculated per individual deer. Data from recollared animals were averaged to avoid over estimating visitation. Farm and cattle-use area visits were defined as a deer location recorded within the farm or cattle-use area. For yards, a proximity threshold similar to other studies was used to classify visitation (Cooper et al. 2010; Habib et al. 2011). It is likely that visits occurred but were not recorded due to the relatively small size of yards, potential error in the locations, and the relatively coarse 2 -h period between locations. To define a proximity threshold for visitation, locations immediately prior to and immediately after a recorded yard visit and the number of visits was tallied for each yard. These data indicated that the mean distance before or after a visit was $89.4 \pm 6.6 \mathrm{~m}$ and $25 \%$ of locations were within $18.7 \mathrm{~m}$. As a result we selected a conservative proximity threshold of $18.7 \mathrm{~m}$ to define visits and this proximity threshold was applied to all locations. To evaluate the relationship between livestock management practices and deer use of farms, farms were classified as having high deer use or low deer use. Farms with fewer than ten deer visits were classified as having low deer use while farms with ten or more visits were classified as having high deer use.

Statistical analyses of livestock management practices and deer visitation of farms was performed using commercial 
statistical software (S-PLUS, TIBCO Software, Inc., CA and SAS v.9.2 SAS Institute, NC). The basic sampling unit is defined as individual deer. Visitation of farms, yards, and cattle-use areas (number of tallied visits) by individual deer were summarized via descriptive analysis and reported as proportions with $95 \%$ confidence intervals (CI) or \pm standard errors (SE) by month and daily. Measures of individual deer activity (number of visits) were classified into two primary diel periods to identify peak times of activity: daytime (sunrise to sunset), and nighttime (sunset to sunrise). Each diel period was further divided into two sub-categories to identify peak times of activity within the primary diel period. Daytime visits were divided into "morning" (sunrise to noon) and "afternoon" (noon to sunset) categories. Nighttime visits were further classified as "sunset to midnight" or "midnight to sunrise." Proportions were compared using the FREQ procedure in SAS (SAS Institute, North Carolina) with a null hypothesis of equal proportions $\left(H_{\mathrm{o}}: \bar{x}=0.50\right)$. Statistical significance is given at $P<0.05$.

Univariate analysis was used to evaluate if livestock management practices were associated with increased deer visitation of farms. Multivariate analysis, while often the most useful in understanding interactions and controlling for confounding of independent variables, was not used due to very small sample size of farms $(n=19)$ and deer $(n=16)$. Fifteen livestock management practice parameters were compared with each farms deer use classification (low versus high use) using $\chi^{2}$ analysis and $t$ tests. Odds ratios (OR) with $95 \%$ CI were computed for each livestock management parameter and, due to small sample sizes, significance was evaluated using Fisher exact test using two statistical significance levels of $P<0.05$ and $P<0.10$. To correct for multiple comparisons we used the Benjamini-Hochberg procedure. We evaluated all parameters at using a false discovery rate of 0.5 and 0.2 and conservatively considered all livestock management parameters as one "family" of tests (Benjamini and Hochberg 1995).

\section{Results}

\section{Capture results}

We captured 25 adult does during 2,357 trap nights from 19 January-16 March 2007 and 5 January-5 March 2008 and deployed 27 collars (two deer collared in 2007 were recollared in 2008). Sixteen collars were deployed in 2007, and 11 were deployed in 2008. Fourteen deer were collared at site one (two were re collars), eight at site two, two at site three and three at site four. No adult bucks entered the traps during either trapping season, thus the only adult deer collared were does.
Collar recovery and performance

Eighteen collars from 16 different study deer were recovered and 54,255 data points were downloaded. Twelve collars released automatically after 12 months as programmed and were recovered (one of these was recovered during recapture when the collar had released but not yet dropped off). Four collars were recovered following hunter harvest but prior to their programmed release: one was collected after 5 months, two were collected after 9 months and one after 10 months. Two collars did not release as programmed but were retrieved (one following a deer-vehicle collision and another during recapture). Both of these collars recorded data for 12 months as programmed. Nine collars (33.3\%) were never retrieved due to a variety of problems, including lost signals and battery failures. The bTB status of the five deer mortalities remains unknown as they were not submitted for testing.

Home range estimate

Mean $( \pm$ SE) annual home range size was $141.3 \pm 27.6$ ha, which was consistent with those previously reported for white-tailed deer in Michigan by Garner (2001) but smaller than reports by Sitar (1996). Home range size varied with season, increasing to $192.2 \pm 114.8$ ha in December and 167.1 \pm 38.3 ha in March, while constraining to $51.0 \pm 6.8$ ha in June (Fig. 2). Home ranges also varied by seasonal breeding periods of gestation (January-April), fawning (May-August), pre-rut (September-October) and rut (November-December) and were $124.0 \pm 12.1$ ha, $63.3 \pm 5.2$ ha, $79.6 \pm 10.7$ ha, 154.3 \pm 53.1 ha, respectively. Study deer had on average $20 \pm 3.1 \%$ of their annual home range within another study deer's home range and home ranges included on average $4.1 \pm 0.5$ other collared deer.

Farm visitation

Farms

Twenty farms were present within the home range of all study deer. Of these 20 farms, producer surveys were completed for 19. The majority of farms were beef cattle farms $(80 \%)$ and the remaining (20\%) farms were dairy operations. Producer reported cattle inventories (animals of all ages) on these farms averaged $35 \pm 15$ animals for beef and $26 \pm 2$ animals for dairy and ranged from 9 to 250 animals. All farms reported the use of hay as feed for cattle and $11(58 \%)$ reported using grain as cattle feed. All but one farm (95\%) reported some form of feed storage, however only $53 \%$ of farms reported enclosed feed storage. Hay storage included use of agricultural bags, barns, enclosed fencing, piling, and stacking bales along fence lines. Grain storage included storage in barns, gravity feeders, or garage. Cattle feeding frequency varied from twice daily to 
Fig. 2 Mean $( \pm \mathrm{SE})$ monthly $95 \%$ fixed kernel home range (hectares) for all deer in study. Months of July and September had reduced sampling frequency

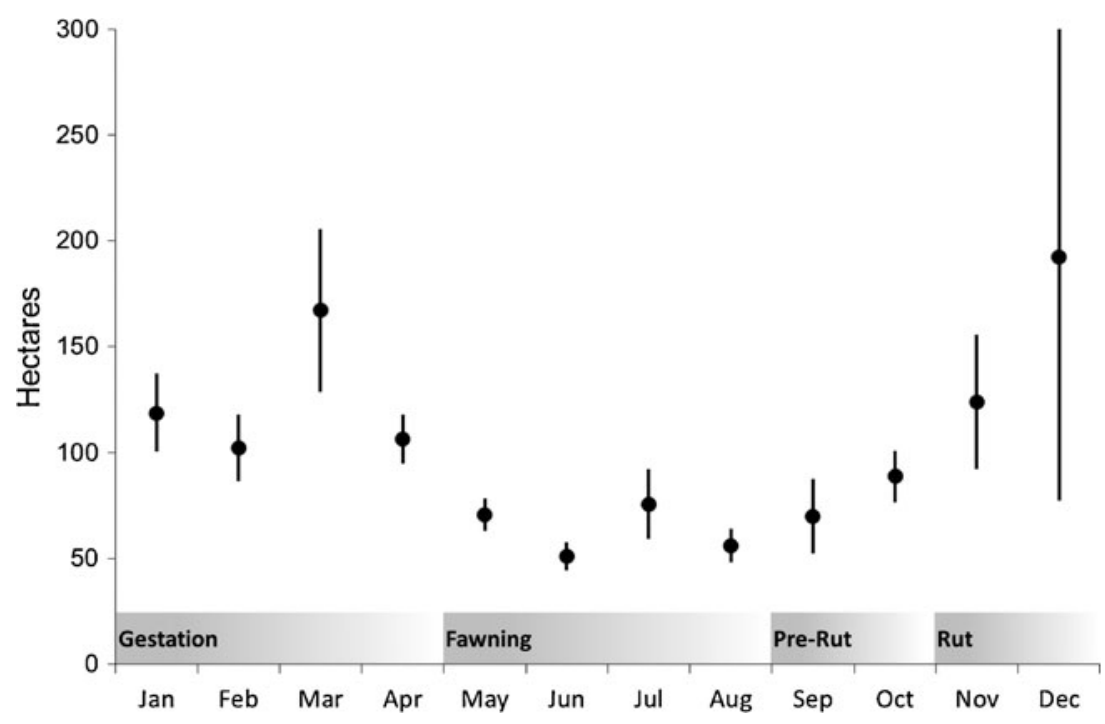

once a week. Use of confined feeding was common with $58 \%$ of the farms reporting the practice. Use of confined feeding areas was generally restricted to winter; however, some producers reported use through late spring. Dog ownership was common with $89 \%$ of farms having at least one dog (range, 1-3). Dogs were confined in the farmhouse, in an outdoor kennel, or allowed to roam free. Deer hunting was common with $63 \%$ of farms reporting some type of hunting.

Annual home ranges of all deer included at least one farm $(\bar{x}=2.3 \pm 0.4)$ and deer visited nearly all farms within their home ranges $(\bar{x}=96.4 \pm 2.7 \%)$. An average of $40 \pm 3.5 \%$ of study deer home ranges were occupied by farms, and there was no difference between deer visiting farms and deer not visiting farms $(t=1.43, P=0.083)$. Farm size (hectares) did not differ between study deer that visited farms and those that did not visit farms $(t=1.38, P=0.090)$. Farms on average were included in the home range of $2.6 \pm 0.5$ study deer. Additionally, farms with visits and farms without visits were included in the home range of a similar number of collared deer $(t=1.46, P=0.081, P>0.1)$. Seven study deer visited at least one farm $(\bar{x}=1.7 \pm 0.2)$ outside their annual home range. Study deer visited farms throughout the year, although the majority of visitation $(75.0 \pm 3.7 \%)$ occurred from January through June with the peak of visitation occurring in April $(17.3 \pm 2.8 \%)$ (Fig. 1). There were slightly fewer farm visits at night $(\bar{x}=0.42,95 \% \mathrm{CI}: 0.36,0.49)$ than during the day. However, of the visits at night, a higher proportion occurred between midnight and sunrise ( $\bar{x}=0.58,95 \% \mathrm{CI}: 0.53,0.63)$ than between sunset and midnight. Nine farms had fewer than ten deer visits and, for the purpose of evaluating livestock management practices, were classified as having low deer use. Eleven farms had greater than ten visits and were classified has having high deer use, with the number of visits to these farms ranging from 16 to $6155(\bar{x}=664 \pm 363)$. However, one of these farms did not complete a producer survey resulting in ten farms classified as having high deer use.

Yards

There were 11 yards within the home range of all study deer. Two were located on dairy farms and nine were located on beef cattle farms. Ten study deer (62.5\%) visited a yard at least once and had home ranges that included at least one yard $(\bar{x}=1.8 \pm 0.4)$. Yards present within the home range of study deer were small (25.9 $\pm 3.0 \mathrm{ha})$ and also did not differ between study deer that visited farms and those that did not visit farms $(t=1.47, P=0.049)$. Six study deer $(37.5 \%)$ were not documented visiting yards during the study period although they had a similar number of yards $(t=1.47, P=0.048)$ available in their annual home ranges $(\bar{x}=1.0 \pm 0.2)$ and the proportion of their annual home range classified as farms was similar ( $t=1.43, P=0.086)$.

Study deer that visited yards visited $80.1 \pm 13.3 \%$ of yards within their annual home range at least once during the study. Three study deer (19\%) accounted for $88 \%$ of yard visits. A higher proportion $(\bar{x}=0.76,95 \% \mathrm{CI}: 0.73,0.79)$ occurred at night than during the day, and a higher proportion of nighttime visits $(\bar{x}=0.69,95 \% \mathrm{CI}: 0.65,0.72)$ occurred between midnight and sunrise. During the day, a higher proportion of visits occurred between sunrise and noon $(\bar{x}=0.59,95 \%$ CI: 0.52 , $0.65)$ than between noon and sunset. Similar to farms, study deer visited yards throughout the year with the majority of visitation $(71.7 \pm 3.1 \%)$ occurring from January through June with the peak of visitation occurring in June.

Visits to two or more different yards on the same day were common, occurring 207 times during the study. Five deer (50\% using yards) visited multiple yards on the same day at least once and two deer visited up to three yards on the same day. Visits to multiple yards occurred in all months; however, June 
experienced twice as many multiple visits as other months. Yards that were visited on the same day were generally close in proximity $(496.8 \pm 122.6 \mathrm{~m})$. Beef farms accounted for $95.7 \%$ of yard visitation and two study deer visited a yard outside their annual home range.

\section{Cattle-use areas}

On average, there were $6.8 \pm 1.3$ cattle-use areas within the home range of each study deer, totaling 109 cattle-use areas within the study area. Study deer visited an average $74.1 \pm 6.3 \%$ of cattle-use areas within their home ranges. All deer visited cattle-use areas at least once during the study period, with $43 \%$ of the deer accounting for $80 \%$ of use. Deer visited cattle-use areas throughout the year, although the majority of visitation $(81.1 \pm 3.8 \%)$ occurred from January through June, and three months (April, May and June) accounted for a disproportionate $(46.1 \pm 8.0 \%)$ amount of use. There was no difference in the proportion of visits at night $(\bar{x}=0.50,95 \%$ CI: $0.48,0.51)$ versus during the day. However, of the visits at night, a higher proportion occurred between midnight and sunrise $(\bar{x}=0.57$, $95 \%$ CI: $0.55,0.59)$ than between sunset and midnight. During the day, a higher proportion of visits occurred between noon and sunset $(\bar{x}=0.60,95 \%$ CI: $0.57,0.62)$

\section{Livestock management practices}

Fifteen study farm infrastructure, animal husbandry, and human activity parameters were captured in producer interviews (Table 1). Three study farm infrastructure characteristics: presence of a confined feeding area (OR 15.75; $95 \%$ CI: $1.69,229.42)$, greater than one cattle water tub (OR 10.80; $95 \%$ CI: $0.79,319.81)$ and greater than two cattle pastures (OR 5.63; $95 \%$ CI: 0.71, 55.47) present on farms were associated with deer visitation. All other study farm infrastructure characteristics evaluated had OR greater than one; however, none were statistically significant at the 5 or $10 \%$ levels of significance. None of the cattle feeding practices evaluated were statistically significant; however, time of feeding (evening versus day) and feeding of grain to cattle were estimated to have OR greater than one. Only one human activity practice, the number of dogs present on study farm, was significant but was negatively associated with deer visitation.

\section{Discussion}

The management of zoonotic pathogens is often complicated by the presence of wildlife reservoirs, presenting challenges for control and eradication. Understanding when and where wildlife and livestock may interact can improve mitigations designed to address transmission of zoonotic pathogens. In our study, a minority of deer (19-43\%) were responsible for
Table 1 Odds ratios of association between farm infrastructure, cattle feeding practices, and human activity and farm visitation by deer $(n=19$ for farms and $n=16$ for deer)

\begin{tabular}{|c|c|c|c|c|}
\hline Risk factor $^{\mathrm{a}}$ & $\begin{array}{l}\text { Odds } \\
\text { ratio }\end{array}$ & $\begin{array}{l}\text { CI odds } \\
(95 \%)\end{array}$ & $\begin{array}{l}P \\
\text { value }^{\mathrm{b}}\end{array}$ & $\begin{array}{l}\text { Benjamini- } \\
\text { Hochberg }^{\mathrm{c}, \mathrm{d}}\end{array}$ \\
\hline \multicolumn{5}{|l|}{ Farm infrastructure } \\
\hline $\begin{array}{l}\text { Number of cattle } \\
(\leq 20,>20)\end{array}$ & 2.00 & $0.29,15.02$ & 0.463 & \\
\hline $\begin{array}{l}\text { Confined feeding area } \\
\text { (present, absent) }\end{array}$ & 15.75 & $1.69,229.42$ & 0.008 & $-^{\mathrm{c}}$ \\
\hline $\begin{array}{l}\text { Number of pastures } \\
(\leq 2,>2)\end{array}$ & 5.63 & $0.71,55.47$ & 0.081 & $-^{\mathrm{d}}$ \\
\hline $\begin{array}{l}\text { Feed storage (present, } \\
\text { absent) }\end{array}$ & 1.38 & $0.04,45.51$ & 0.830 & \\
\hline $\begin{array}{l}\text { Hay storage } \\
\text { (confined/ } \\
\text { unconfined) }\end{array}$ & 2.19 & $0.34,15.28$ & 0.391 & \\
\hline $\begin{array}{l}\text { Grain storage } \\
\text { (confined/ } \\
\text { unconfined) }\end{array}$ & 5.25 & $0.27,190.87$ & 0.185 & \\
\hline Water tub $(\leq 1,>1)$ & 10.80 & $0.79,319.81$ & 0.031 & $-^{\mathrm{c}}$ \\
\hline \multicolumn{5}{|l|}{ Feed practices } \\
\hline $\begin{array}{l}\text { Feed time (evening/ } \\
\text { day) }\end{array}$ & 1.67 & $0.20,14.89$ & 0.614 & \\
\hline $\begin{array}{l}\text { Grain feeding } \\
\text { (conducted/not } \\
\text { conducted) }\end{array}$ & 2.19 & $0.34,15.28$ & 0.391 & \\
\hline $\begin{array}{l}\text { Hay feeding } \\
\text { (conducted/not } \\
\text { conducted) }\end{array}$ & - & - & - & \\
\hline $\begin{array}{l}\text { Time of hay feeding } \\
\text { (winter/summer) }\end{array}$ & 0.25 & $0.01,2.81$ & 0.243 & \\
\hline $\begin{array}{l}\text { Type of hay feeding } \\
\text { (chip/bales) }\end{array}$ & 0.35 & $0.01,5.10$ & 0.413 & \\
\hline \multicolumn{5}{|l|}{ Human activity } \\
\hline $\operatorname{Dogs}(\leq 1,>1)$ & 0.00 & $0.00,2.53$ & 0.099 & $-^{\mathrm{d}}$ \\
\hline $\begin{array}{l}\text { Dog storage } \\
\text { (confined/ } \\
\text { unconfined) }\end{array}$ & 0.43 & $0.05,3.27$ & 0.387 & \\
\hline $\begin{array}{l}\text { Hunting (conducted/ } \\
\text { not conducted) }\end{array}$ & 2.92 & $0.39,25.90$ & 0.279 & \\
\hline
\end{tabular}

${ }^{\text {a }}$ Nineteen of 20 producers completed surveys

${ }^{\mathrm{b}} P$ values calculated using Fischer exact test

${ }^{\mathrm{c}}$ Benjamini-Hochberg adjusted statistical significance using a false discovery rate of 0.2

${ }^{\mathrm{d}}$ Benjamini-Hochberg adjusted statistical significance using a false discovery rate of 0.5

${ }^{\mathrm{e}}$ Hay feeding was evaluated; however, all producers used hay for cattle feeding during the study

the majority ( $80-88 \%)$ of visits to farms, yards, and cattle-use areas which were concentrated in late spring. Yard use increased beginning in April and reached an apex in June near the peak fawning period, which ranges from May 31 to June 10 for the region (Ozoga et al. 1982; Verme 1989) (Fig. 3). Use declined rapidly after June 1 reaching a minimum in July, although the reduction of visits in July may be associated with the reduced locational fix frequency. Despite this reduction, 


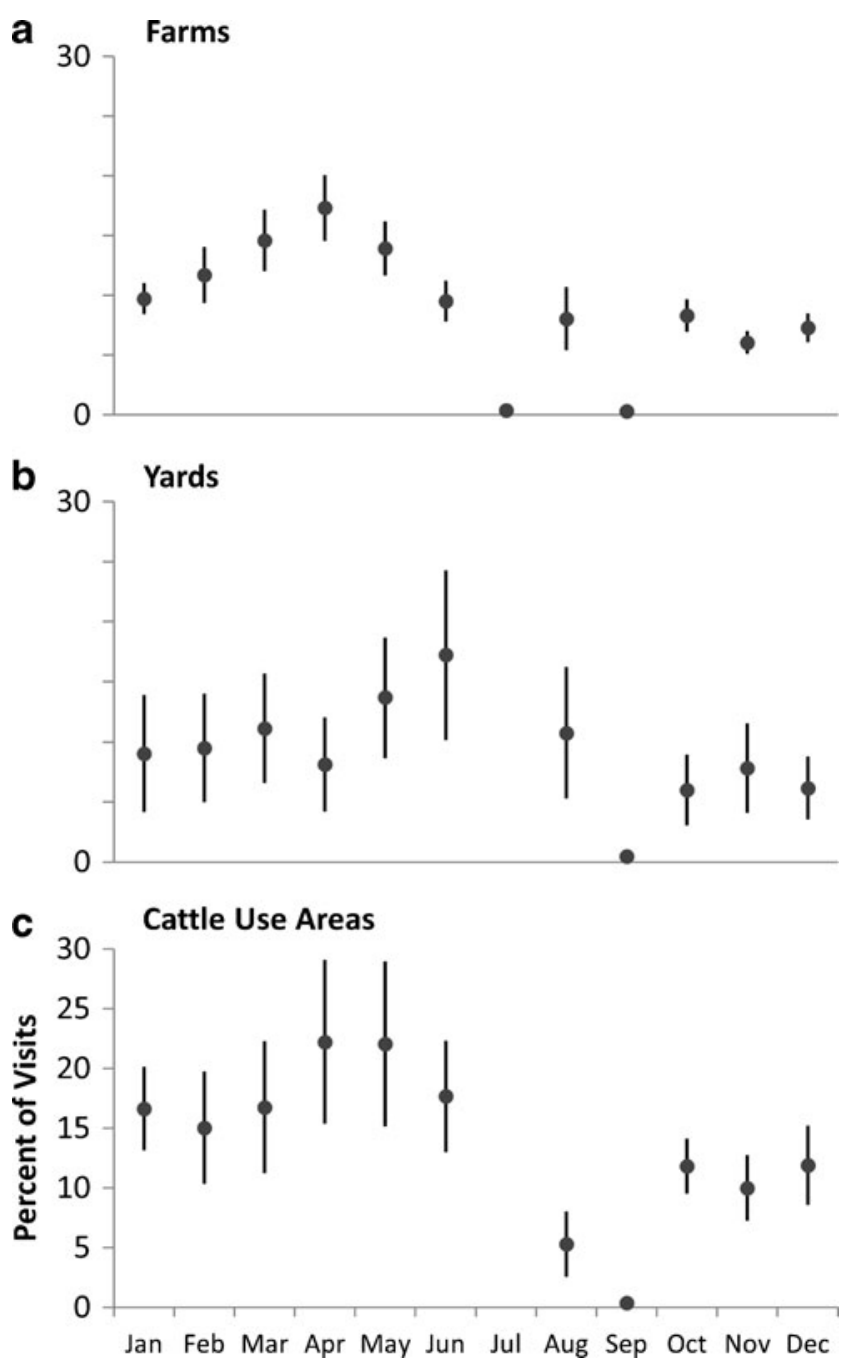

Fig. 3 Mean $( \pm S E)$ number of visits by white-tailed deer to $\mathbf{a}$ farms, $\mathbf{b}$ yards, and $\mathbf{c}$ cattle-use areas throughout a year. The months of July and September had reduced sampling frequency

we did observe a trend of reduced visits during the summer fawning period. Study farm infrastructure related to cattle feeding (confined feeding, cattle pastures, and water source) were associated with deer visitation.

Cattle feeding practices may contribute to the deer use of farms, and thus the potential transmission of bTB from deer to cattle through shared feed. The number of cattle pastures and the presence of confined cattle feeding areas were associated with deer use of the study farms. It is common in small cattle production systems - such as those in this study area - to use confined feeding as an efficient method of locating cattle near feed. Furthermore, it is common to store cattle feed (hay, silage, etc.) in proximity to cattle, either near confined feeding areas or along pasture fence lines, and to feed loose hay. Cattle feeding practices have been associated with farm bTB status in Michigan and with deer damage to stored feed on farms in Minnesota (Kaneene et al. 2002; Knust et al. 2011). Similar to Knust et al. (2011) the presence of feed storage on farm was not significantly associated with deer use indicating that feeding practices may be a more important risk factor. Cattle feeding practices that concentrate animals on farms may result in unconsumed feed inadvertently providing an additional source of forage for deer. Water sources may also play a role in farm visitation. A significant association between farm visitation and the number of cattle water sources was found in our study. Kaneene et al. (2002) found a similar relationship between a farm's bTB infection status and the presence of water sources in cattle pastures. While the mechanisms responsible for patterns of visitation are unclear, physiological, or behavioral processes associated with forage availability may be a contributing factor.

One potential physiological explanation for increased visitation of study farms in late spring might be increasing caloric needs associated with gestation (Moen 1978). Seasonal visits appear to correspond to increasing protein and metabolizable energy intake of pregnant female deer in the third trimester of gestation (Moen 1978; Pekins et al. 1998; Parker et al. 1999). Substantial energy costs are associated with gestation, particularly the third trimester when $82 \%$ of fetal growth occurs (Armstrong 1950); and it is plausible that this contributes to visitation. While there was no data on the pregnancy status of animals in this study, it can be assumed that the majority (>90\%) of deer were pregnant (Friedrich 1979; Harder 1980). Other potential explanations for deer use of study farms coinciding with fawning may be behavioral. One potential explanation is refuging from predation during fawning. Grund et al. (2002) found deer avoided areas of human activity during the fawning season and Hiller et al. (2008) suggested deer retreated to conifer and lowland deciduous forests to avoid predation. In our study, deer were not deterred by the presence of farm dogs and it is possible that wooded areas (i.e., tree rows) adjacent to yards act as refuge for fawning deer. The physiological and behavioral mechanisms driving this pattern of farm use remain unclear and warrant further investigation.

\section{Disease management implications}

Challenges faced by wildlife managers and livestock authorities in mitigating contact (direct and indirect) between wildlife and livestock has resulted in technology that reduces contact. However, the development of effective tools to mitigate contact and potential transmission of diseases such as bTB has been met with many challenges. Mechanical devices prove to be ineffective or only effective for a short duration (VerCauteren et al. 2005; VerCauteren et al. 2006a, b). Physical exclusion via various forms of fencing may be effective, but is often cost-prohibitive, labor-intensive or suffers from lack of maintenance and gate closure (Lavelle et al. 2009; VerCauteren et al. 2006a; b). Targeted culling and vaccination have been demonstrated as an effective approach for disease control (Griffin et al. 2005; Haydon et al. 2006). However, 
common disease management tools such as population reduction or vaccination are often controversial, resource intense, or nonspecific (Rhyan and Spraker 2010) and may not be appropriate in all situations. Methods to identify high-risk deer for selective culling or vaccination are limited and have been identified as a critical gap in research (Sweeney and Miller 2010). Improved understanding of the mechanisms driving deer seasonal use of livestock production areas where contact can occur has benefits for improving contact mitigation, targeting culling, or vaccination efforts.

Our data indicate that a small proportion of deer might be disproportionately responsible for farm visitation and presumably at higher risk for transmission of pathogens. However, we acknowledge that our data are limited to does, as no bucks were captured. Bucks are more likely to be bTB-positive than does (O'Brien et al. 2002) and should be included in any mitigation methods considered. For pathogens that can be transmitted between livestock and wildlife, the risk for transmission often increases near farms (Palmer et al. 2004). Focusing on culling, vaccine deployment or other mitigation methods on farms may serve as a logistically and financially effective method to target deer that are at highest risk for transmission of pathogens between livestock. Our data suggest that deer visit farms, yards, and cattle-use areas at night and typically between midnight and sunrise with minor activity peaks between sunrise and noon. Therefore, mitigation activities could be performed during nighttime hours to target those deer that have a higher potential for disease transmission by interacting with cattle and cattle resources.

\section{Conclusion}

This study provides insight into deer use of yards and cattleuse areas, which may contribute to the spread of bTB between deer and cattle. The seasonal nature of shared resources between cattle and deer may offer opportunities to optimize mitigation efforts. Mitigations could be performed at night in spring when visits appear to peak. In addition, because a small proportion of deer are responsible for the majority of farm visits, mitigation efforts can be focused to target individual deer.

Livestock management practices may inadvertently result in attracting deer onto farms by allowing uneaten feed to remain in pastures or feeding areas. One potential mitigation method to reduce the likelihood of deer consumption of such feed, and thus the risk of indirect disease exposure, is to employ confined feeding regimens for cattle using dedicated feeding zones that are fenced to prevent deer access. The authors acknowledge that variability in individual management practices and financial constraints play a role in the feasibility of such endeavors. However, it may be possible to restrict costly or labor-intensive mitigation methods to previously infected farms, reducing the potential for re-infection.

While our data demonstrate trends in deer visits to farms, farm yards, and cattle-use areas, there are limitations. It is possible that deer in the study were members of single or multiple family units which may bias any population level inference from these data. We did not assess the degree of relatedness among captured deer which is a limitation to our study. Blanchong et al. (2007) found that bTB-infected deer were more closely related than non-infected deer and suggested infection was a result of deer to deer transmission. This also suggests that social structure is important for pathogen transmission and may be important for understanding behaviors associated with cattle farm visitation. It is possible that farm yard and cattle-use area visitation is a learned behavior associated with social structure but whether infection occurs as a result of gregarious feeding on the same infected food source or through social interactions requires further research. In addition, only does were collared during this study. This was not by design but likely a factor of buck/doe ratios. Regional buck/doe ratios are lower than the state goal of 37:100 (Anonymous 2010). As a result, there were fewer available males for capture.

Additional research is needed to address behavioral, environmental, or anthropogenic factors that contribute to deer use of farms. Larger studies that incorporate both greater numbers of deer along with more detailed animal husbandry practice data and the infection status of cattle and deer would further elucidate risks for transmission of pathogens.

Acknowledgments The authors wish to thank the following: USDA/ Wildlife Services, Gaylord, Michigan for logistic support and office space and Minnesota Department of Natural Resources for trapping supplies. Thanks to C. Fitzpatrick, T. Fry, S. Johnson, D. Kilpatrick, R. Pleszewski, and T. Riley for trapping assistance. We are grateful to P. Riggs for data manipulation. Special thanks to M. Farnsworth for consistent input, critical comment, and intellectually stimulating conversation. Finally, a special note of thanks is extended to the private landowners who cooperated in this study. Funding was provided by USDA/APHIS/Veterinary Services. Capture and handling of deer was approved by the USDA/ APHIS/WS/National Wildlife Research Center's Institutional Animal Care and Use Committee under protocol QA-1343.

\section{References}

Anonymous (2010) Michigan deer management plan. Michigan Department of Natural Resources and Environment. Wildlife Division Report No. 3512

Anonymous (2007) Quick stats data base. United States Department of Agriculture, National Agricultural Statistics Service

Armstrong R (1950) Fetal development of the northern white-tailed deer (Odocoileus virginianus borealis). Am Midl Nat 43:650-666

Benjamini Y, Hochberg Y (1995) Controlling the false discovery rate: a practical and powerful approach to multiple testing. J Roy Stat Soc B Met 57:289-300 
Blanchong J, Scribner K, Kravchenko A, Winterstein S (2007) TBinfected deer are more closely related than non-infected deer. Biol Lett 3:104

Böhm M, Hutchings MR, White PCL (2009) Contact networks in a wildlife-livestock host community: identifying high-risk individuals in the transmission of bovine TB among badgers and cattle. PloS One 4:e5016

Carlson JC, Franklin AB, Hyatt DR, Petit SE, Linz GM (2011) The role of starlings in the spread of Salmonella within concentrated animal feeding operations. J Appl Eco 48:479-486

Coleman J (1988) Distribution, prevalence, and epidemiology of bovine tuberculosis in brushtail possums, Trichosurus vulpecula, in the Hohonu Range, New Zealand. Aust Wildlife Res 15:651-663

Coleman J, Cooke M (2001) Mycobacterium bovis infection in wildlife in New Zealand. Tuberculosis 81:191-202

Cooper S, Scott H, De La Garza G, Deck A, Cathey J (2010) Distribution and interspecies contact of feral swine and cattle on rangeland in South Texas: implications for disease transmission. J Wildlife Dis 46:152-164

Cosivi O, Grange J, Daborn C, Raviglione M, Fujikura T, Cousins D, Robinson R, Huchzermeyr H, De Kantor I, Meslin F (1998) Zoonotic tuberculosis due to Mycobacterium bovis in developing countries. Emerg Infect Dis 4:59-70

Delahay R, De Leeuw A, Barlow A, Clifton-Hadley R, Cheeseman C (2002) The status of Mycobacterium bovis infection in UK wild mammals: a review. Vet J 164:90-105

Frawley BJ, Rudolph BA (2008) Deer hunter opinion survey, 2006. Michigan Department of Natural Resources, Lansing, MI, p 29

Fredriksen B, Djønne B, Sigurdardsdóttir Ò, Tharaldsen J, Nyberg O, Jarp J (2004) Factors affecting the herd level of antibodies against Mycobacterium avium subspecies paratuberculosis in dairy cattle. Vet Rec 154:522-526

Friedrich, PD (1979) Doe productivity and physical condition: 1979 spring survey results. Michigan Department of Natural Resources. $12 \mathrm{pp}$

Frye GH (1995) Bovine tuberculosis eradication: the program in the United States. In: Thoen CO, Steele JH (eds) Mycobacterium bovis infection in animals and humans. Iowa State University Press, Ames, IA, pp 119-129

Gallagher J, Clifton-Hadley R (2000) Tuberculosis in badgers: a review of the disease and its significance for other animals. Res Vet Sci 69:203-217

Gannon WL, Sikes RS (2007) Guidelines of the American society of mammalogists for the use of wild mammals in research. J Mammal 88:809-823

Garner M (2001) Movement patterns and behavior at winter-feeding and fall baiting stations in a population of white-tailed deer infected with bovine tuberculosis in the northeastern lower Peninsula of Michigan. Dissertation. Michigan State University

Griffin J, Williams D, Kelly G, Clegg T, O’Boyle I, Collins J, More S (2005) The impact of badger removal on the control of tuberculosis in cattle herds in Ireland. Prev Vet Med 67:237-266

Grund MD, McAninch JB, Wiggers EP (2002) Seasonal movements and habitat use of female white-tailed deer associated with an urban park. J Wildlife Manage 123-130

Habib TJ, Merrill EH, Pybus MJ, Coltman DW (2011) Modelling landscape effects on density-contact rate relationships of deer in eastern Alberta: implications for chronic wasting disease. Ecol Model 222:2722-2732

Harder J (1980) Reproduction of white-tailed deer in the north central United States. In: Hine RL, Nehls S (eds). Proceedings (1979) Symposium North Central Section Wildlife. pp. 23-35

Haydon D, Randall D, Matthews L, Knobel D, Tallents L, Gravenor M, Williams S, Pollinger J, Cleaveland S, Woolhouse M (2006) Lowcoverage vaccination strategies for the conservation of endangered species. Nature 443:692-695
Hiller TL, Campa H III, Winterstein SR, Rudolph BA (2008) Survival and space use of fawn white-tailed deer in southern Michigan. Am Midl Nat 159:403-412

Kaneene J, Bruning-Fann C, Granger L, Miller R, Porter-Spalding B (2002) Environmental and farm management factors associated with tuberculosis on cattle farms in northeastern Michigan. J Am Vet Med Assoc 221:837-842

Kaneene J, Pfeiffer D (2006) Epidemiology of Mycobacterium bovis. In: Thoen CO, Steele JH, Gilsdoorf MJ (eds) Mycobacterium bovis infection in animals and humans, 2nd edn. Blackwell, Ames, IA, pp 34-48

Knust BM, Wolf PC, Wells SJ (2011) Characterizing risk of deer-cattle interactions in Minnesota with an on-farm environmental assessment tool. Am JVet Res 72:924-931

Lavelle MJ, Fischer JW, Hyngstrom SE, White JJ, Hildreth AM, Phillips GE, VerCauteren KC (2009) Response of deer to containment by a poly-mesh fence for mitigating disease outbreaks. J Wildlife Manage $74: 1620-1625$

Linz G, Homan H, Gaukler S, Bleier L, Penry W (2007) European starlings: a review of an invasive species with far-reaching impacts. In: Witmer GW, Pitt WC, Fagerstone KA (eds) Managing vertebrate invasive species: proceedings of an international symposium. USDA/APHIS/WS/National Wildlife Research Center, Fort Collins, pp 377-386

Miller RS, Sweeney SJ (2013) Mycobacterium bovis (bovine tuberculosis) infection in North American wildlife: current status and opportunities for mitigation of risks of further infection in wildlife populations. Epidemiol Infect 141:1357-1370

Miller R, Kaneene JB, Fitzgerald SD, Schmitt SM (2003) Evaluation of the influence of supplemental feeding of white-tailed deer (Odocoileus virginianus) on the prevalence of bovine tuberculosis in the Michigan wild deer population. J Wildlife Dis 39:84

Miller RS, Farnsworth ML, Malmberg JL (2012) Diseases at the livestock-wildlife interface: status, challenges, and opportunities in the United States. Prev Vet Med 110:119-132

Millian-Suazo F, Harris B, Diaz CA, Torres CR, Stuber T, Ojeda GA, Loredo AM, Soria MP, Payeur JB (2008) Molecular epidemiology of Mycobacterium bovis: usefulness in international trade. Prev Vet Med 87:261-271

Moen AN (1978) Seasonal changes in heart rates, activity, metabolism, and forage intake of white-tailed deer. J Wildlife Manage 42:715738

Morellet N, Verheyden H, Angibault J, Cargnelutti B, Lourtet B, Hewison M (2009) The effect of capture on ranging behaviour and activity of the European roe deer Capreolus capreolus. Wildlife Biol 15:278-287

O'Brien DJ, Schmitt SM, Fitzgerald SD, Berry DE (2011) Management of bovine tuberculosis in Michigan wildlife: current status and near term prospects. Vet Microbiol 151:179-187

O'Brien DJ, Schmitt SM, Fierke JS, Hogle SA, Winterstein SR, Cooley TM, Moritz WE, Diegel JL, Fitzgerald SC, Berry DE, Kannene JB (2002) Epidemiology of Mycobacterium bovis in free-ranging white-tailed deer, Michigan USA, 1995-2000. Pre Vet Med 54:47-63

Ozoga JJ, Verme LJ, Benze CS (1982) Parturition behavior and territoriality in white-tailed deer: impact on neonatal mortality. J Wildlife Manage 46:1-11

Palmer MV, Waters WR, Whipple DL (2004) Investigation of the transmission of Mycobacterium bovis from deer to cattle through indirect contact. Am J Vet Res 65:1483-1489

Parker KL, Gillingham MP, Hanley TA, Robbins CT (1999) Energy and protein balance of free-ranging black-tailed deer in a natural forest environment. Wildlife Monogr 143:3-48

Pekins PJ, Smith KS, Mautz WW (1998) The energy cost of gestation in white-tailed deer. Can J Zoolog 76:1091-1097

Portacci K, Lombard J, Fossler C, Bush E, Johnson K, Mitchell D, Weaver T, Pritchard R, Sweeney S, Miller R, Harris R (2010) In: 
Portacci K, Lombard J (eds) Assessment of pathways for the introduction and spread of Mycobacterium bovis in the United States, 2009. USDA APHIS Centers for Epidemiology and Animal Health, Fort Collins, CO, p 135

Portacci KA, Miller RS, Bjørnsen MA, Bush E, Howe R, Lawrnece S, Maleb Z (2008) Assessment of risk associated with the Minnesota proposed plan for split-state status for Mycobacterium bovis (bovine tuberculosis). United States Department of Agriculture, Animal Plant Health Inspection Service, Fort Collins, CO, 121

Rhyan JC, Spraker TR (2010) Emergence of diseases from wildlife reservoirs. Vet Pathol Online 47:34-49

Riley SPD, Hadidian J, Manski DA (1998) Population density, survival, and rabies in raccoons in an urban national park. Can J Zoolog 76:1153-1164

Roper TJ, Garnett BT, Delahay RJ (2003) Visits to farm buildings and cattle troughs by badgers (Meles meles): a potential route for transmission of bovine tuberculosis (Mycobacterium bovis) between badgers and cattle. Cattle Pract 11:9-12

Schmitt SM, Fitzgerald SD, Cooley M, Bruning-Fann CS, Sullivan L, Berry D, Carlson T, Minnis RB, Payeur JB, Sikarskie J (1997) Bovine tuberculosis in free-ranging white-tailed deer from Michigan. J Wildlife Dis 33:749-758

Schmitt SM, O'Brien DJ, Bruning-Fann CS, Fitzgerald SD (2002) Bovine tuberculosis in Michigan wildlife and livestock. Ann NY Acad Sci 969:262-268

Silverman B (1986) Density estimation for statistics and data analysis. Number 26 in Monographs on statistics and applied probability. Chapman \& Hall, London. 175 pp
Sitar KL (1996) Seasonal movements, habitat use patterns and population dynamics of white-tailed deer (Ocodoileus virginianus) in an agricultural region of northern lower Michigan. Thesis. Michigan State University

Sweeney SJ, Miller RS (2010) Free-ranging Wildlife. In: Portacci K, Lombard J (eds) Assessment of pathways for the introduction and spread of Mycobacterium bovis in the United States. United States Department of Agriculture, Animal Plant Health Inspections Service, Fort Collins, CO, p 144

United States Department of Agriculture NRCS National Cartography and Geospatial Center (2007) Available at: http://datagateway.nrcs. usda.gov/GDGHome.aspx. Accessed 13 March 2009.

VerCauteren KC, Beriner J, Hyngstrom SE (1999) Use of netted cage traps for capturing white-tailed deer. In: Proulx G (ed) Mammal trapping. Alpha Wildlife Research \& Management Ltd, Sherwood Park, Canada, pp 155-164

VerCauteren KC, Gilsdorf JM, Hyngstrom SE, Fioranelli PB, Wilson JA, Barras S (2006a) Green and blue lasers are ineffective for dispersing deer at night. Wildlife Soc Bull 34:371-374

VerCauteren KC, Lavelle MJ, Hyngstrom S (2006b) Fences and deerdamage management: a review of designs and efficacy. Wildlife Soc Bull 34:191-200

VerCauteren KC, Shivik JA, Lavelle MJ (2005) Efficacy of an animalactivated frightening device on urban elk and mule deer. Wildlife Soc Bull 33:1282-1287

Verme LJ (1989) Maternal investment in white-tailed deer. J Mammal 70:438-442

White G, Garrot R (1990) Analysis of wildlife radio-tracking data. Academic, San Diego, CA 